\title{
Interview
}

\section{On Private Views, Luxury, and Corruption}

\author{
Andi Schmied interviewed by Tereza $\varnothing$ stbø Kuldova
}

\begin{abstract}
Despite the iconic nature of the Manhattan skyline, there are only four places the public can see it from and those are the Empire State Building, the Rockefeller Center, ONE World Trade Center and the recently opened EDGE at Hudson Yards. All other elevated views are a private privilege, only available to owners of luxury penthouses. Posing as an apartment-hunting Hungarian billionaire, Andi Schmied accessed and documented the views of over thirty of the city's most exclusive high-rise properties. Her book, Private Views: A High-Rise Panorama of Manhattan, offers a glimpse into this elite world. Showcasing the surreal strategies of persuasion used by real estate agents, the book allows readers to bypass the gatekeepers of luxury real estate; guiding them through the sunset from Trump Tower, dawn over Central Park from the tallest residential tower on Earth, and showing samples of the most luxurious materials, such as the Siberian marble, used in soaking tubs overlooking the Statue of Liberty. The skyscrapers visited by Schmied were carefully selected due to their representation of a new type of luxury. Those selected for their architectural interest include the MOMA Expansion Tower by Jean Nouvel, Gehry Tower, Jenga Tower, and 432 Park Avenue. Among the buildings visited for political reasons were the Trump Tower or Time Warner Centre, where recently more than a dozen owners have gone to prison, after anonymously buying an apartment through shell companies. For buildings of economic interest, Schmied visited 220 Central Park South, where its penthouse duplex has been sold for a record sales price. Other buildings selected ranged from reconstructed early American skyscrapers to luxury condos (such as the Woolworth Tower Residences, or 70 Pine) and penthouse suites for sale within luxury hotels (such as the Four Seasons, or Ritz Carlton). Schmied's project is an art and architecture project, but the outcome touches upon various professional fields, such as sociology, economy, urban studies, and anthropology.
\end{abstract}

TØK: Your art explores the architecture of affluence and luxury. How did you come to create an alter ego who could credibly inhabit this architecture?

AS: As an architect, I have been interested in how architecture affects people, so I started to work with the subject, but with an artistic approach I have been mostly focusing on highlighting things I find problematic but always trying to do this through an experiential approach, rather than telling that I have problems with this or that. I am interested in showing things that are hidden or not very obvious to the big audience. This is also how Private Views came about, while I was in New York during a three-month residency program at Triangle Arts Association, in 2016 and that's when I started to work on it. It all started with the biggest cliché: I was just curious of how the city looks from above but at the same time of course I have this history of being 'attracted' to ultra-luxury, so it somehow just made sense to try to research a bit more those spaces of privilege which I just cannot access in any way. So that's how I started to think of how I could get into 


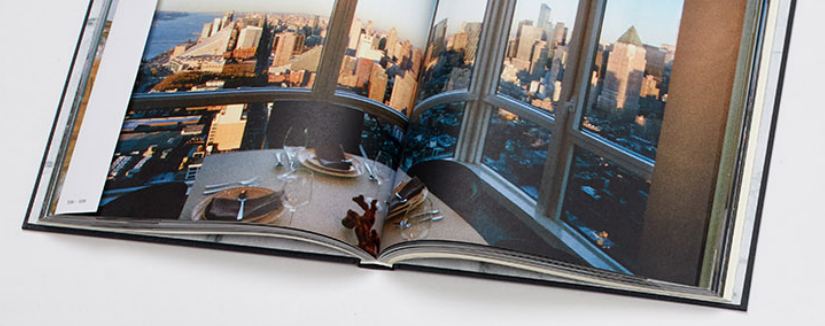




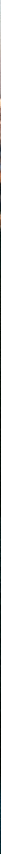

Northern view from one of the penthouse terraces at Kohn Pedersen Fox Associates' 111 Murray. Photo: Andi Schmied. Courtesy of the artist.

sublet your apartment afterwards. This still works in many high-value buildings in New York. But these deluxe supertalls are condominiums, which means that you simply buy an apartment, and a certain percentage of the common areas. This is what we know in Europe. Then, you do whatever you please with your property. So this gave a huge space for shell companies, or other forms of unclear ownership to happen, which is a key to understanding why the ultra-high-net-worth individuals started to buy in New York's ultraluxury supertalls.

TØK: What about the other regulations, such as the zoning regulations, air rights, mechanical and structural voids, and the exploitation of loopholes that enabled the construction of ultra-luxury supertall towers? In a way, void, air and (loop)holes, emptiness, and vacuity, appear to be central to the construction of wealth.

AS: Totally, it's always a bit of playing around the regulations and finding loopholes that allow you to do what you want. One of the crazy things is the 421-a tax incentive, which originated in the 70s, and was a way to motivate developers to build, at a time when real estate wasn't 'a thing'. It is extremely outdated, but because of it, ultra-luxury developments are even getting billions yearly in public funding! Developers are way too powerful, and they would simply never let regulation changes happen. That is also something very strange, because I think they are considered to build living space-and 


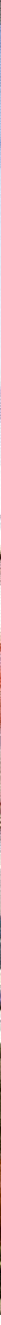

Central Park view from the 100th floor Private Ballroom of Central Park Club. With 1550 feet, Central Park Tower, designed by Adrian Smith and Gordon Gill Architecture, upon completion, will be the tallest residential tower on the planet. Photo: Andi Schmied. Courtesy of the artist.

lots of square meters of it-and that somehow qualifies for public benefits. But these spaces are not really meant for living.

\section{TØK: How do the air rights work?}

AS: Air rights are also very anachronistic, the way they are set. It started in the early 20th century, when they built the Equitable Building which was a super tall building back then, obviously not the tallest anymore today. It cast huge shadows in the neighbouring area, hundreds of meters, which was followed by a public outcry. So, the city started to think of ways how to regulate height, because before that, it was the ad coelum doctrine in vigour, which basically means, 'who owns the land, owns up to the sky, and down to the core of the earth'. But with engineering becoming way more sophisticated, they realised that actually even though it's your plot it's going to affect the neighbours and if it's a very tall building it's going to affect the entire neighbourhood. So, they regulated how high you can build on each plot in New York City. This already gave the pattern and rhythm to entire Manhattan because it regulated the residential areas, the higher office and work areas, and everything in between. Then in the 1960s they started to allow the transfer of these development rights between plots: this is what is colloquially called 'air rights'. Originally, the main goal of this, was historic preservation; they would allow protected, low-rise buildings to sell their unused air-rights, as a way for them to get financial support from neighbouring buildings, that wanted to build higher, but had no permission otherwise to 
135 Questions for Those Who Shape and Those Who (Sometimes) Occupy New York City's Extreme Upper Skyline Samuel Stein

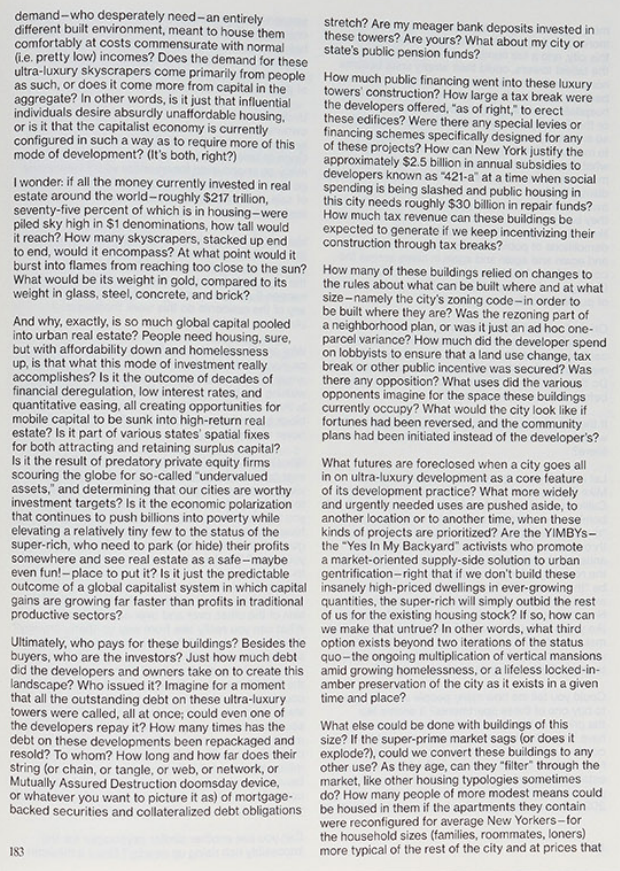

do so. The first precedence of this was the old Penn Station, which is a low rise building but it was in a bad shape, so the neighbour offered that it's going to buy its air rights. This deal could have saved the old structure of Penn Station, and as an exchange the neighbour could have built a 7-story building. At the end this specific transaction did not come across and they renewed the entire Penn Station with other funds, but this was the first precedent of air rights being part of a financial transaction. But as capitalism progressed, air rights became a way for billion-dollar constructions to be able to go as high as the sky. So, for example this area of the Billionaires' Row, the section below the Central Park where most of supertalls are, is technically zoned out. This means that there are no more air rights left because they bought all of them. This is also a kind of good thing for the developers, because on one hand you're extremely tall but you own all those air rights around you. On the other hand, you can be certain that no one is going to block your views, or be higher than you, because there are no more air rights on the market to be purchased. Certainly no one is going to be higher than you and they're never going to block your view in the future. So that's also a plus when you sell the property that you can assure your buyer that the views and the sunshine is never going to be blocked. Whereas in other places, when you buy something, they always can build in front of you. On the other hand, of course, some argue that with one pen stroke they can always correct, and the department of city planning could always just add air rights to any area in the city; it is a bit like printing money. 

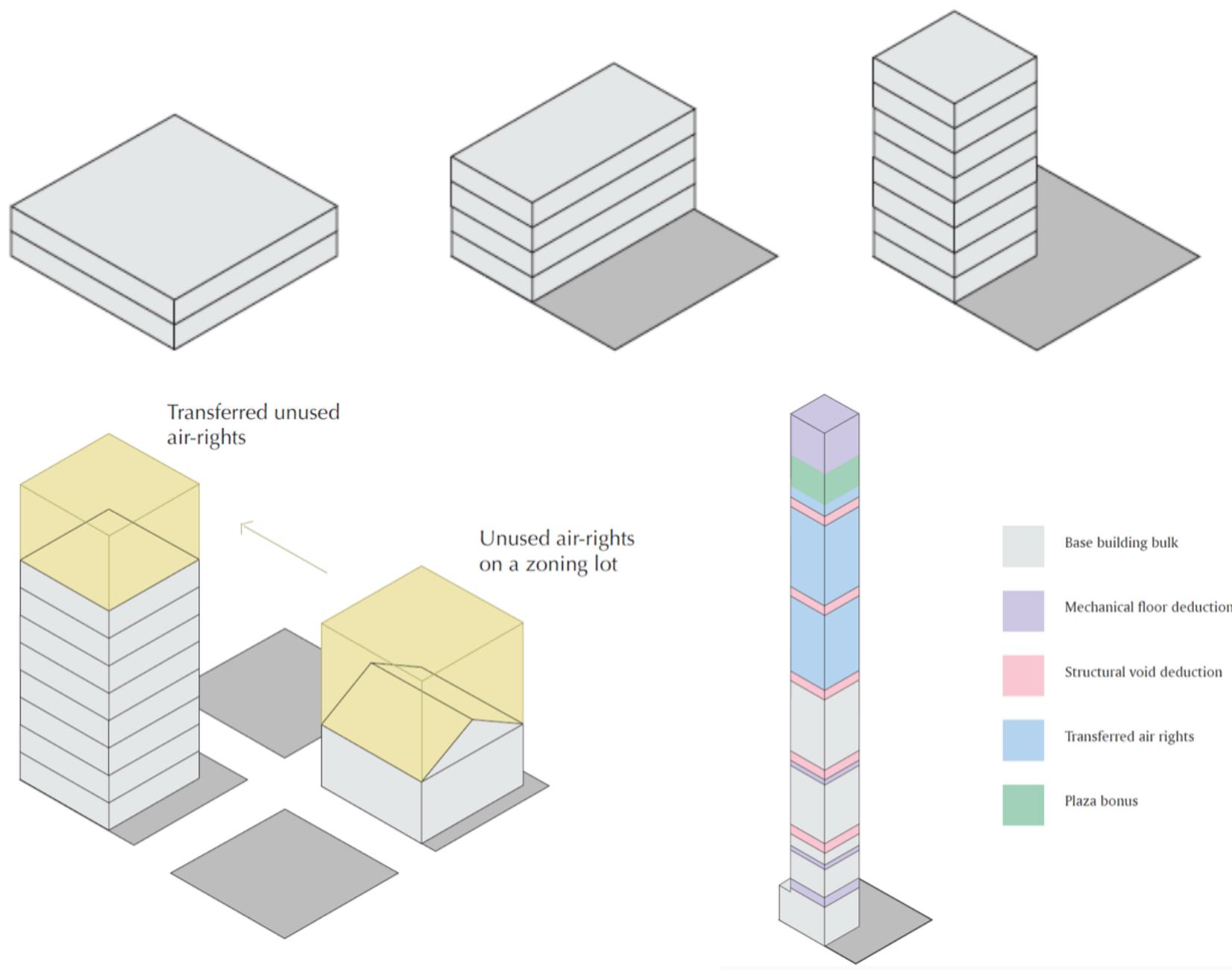

Possible configurations on a hypothetical lot with FAR $=2,0$ (top). Transferable Development Rights (TDRs) (left bottom) Diagram of 432 Park Avenue, showing the use of the above mentioned zoning loopholes (right bottom) Diagrams: Andi Schmied. Courtesy of the artist.

\section{TØK: You can make regulations out of thin air, that's the 'beauty' and luxury of governance.}

AS: And a fun fact, the very first building that was using this technique was Trump Tower, where Trump actually lives now on the 5th Ave, and that was the very first tall luxury residential tower which got to be that high thanks to these a lot of transferred air rights.

\section{TØK: What about these mechanical and structural voids?}

AS: Yeah, that's a proper loophole shamelessly used by developers. So, the way it works is that when you construct, there are certain type of elements that do not count into your total height, for example the mechanical floors; in these huge buildings there are enormous spaces dedicated to plumbing, elevator systems, and so on. Because they are supertall and superslim, they need certain mechanical things to keep them stable and straight. These floors which are there for these purposes, do not count into the overall height, so basically you can add as many mechanical floors as you want and obviously the only reason to use this loophole is to break the records of being the tallest. This is a bit more regulated now and the mechanical void cannot be taller than 30 feet or so. But there was a 5-7-year period when this was not regulated and was used as a loophole. In 



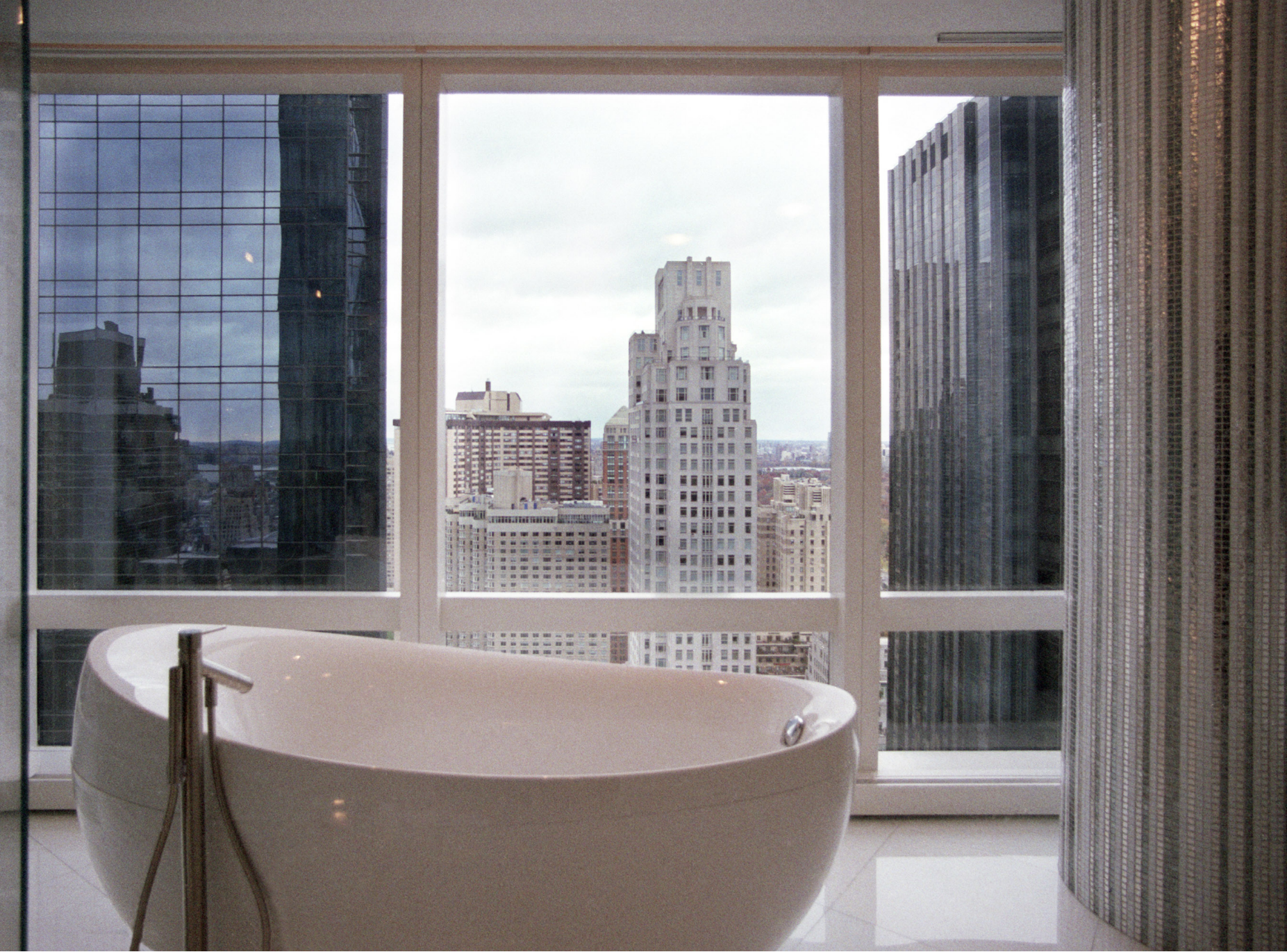

Northern view from one of the upper floor master bathrooms at Time Warner Center designed by Skidmore, Owings \& Merrill. Photo: Andi Schmied. Courtesy of the artist.

AS: The apartments are also constructed in such a way that art has a crucial part in it. In all of the buildings there are huge wall spaces dedicated for paintings, in some there are corridors for sculptures. This actually is quite a big challenge for the interior designers, since most of these spaces are all glass facade, so the 'big white wall' is really specifically made for the display of the owner's art collection. And in some developments, they even have art services, either lending, so you can impress your guests, or they help you to build your own art collection. But at the same time, of course, they assume that buyers have their own anyway.

TØK: Some years ago, Johann Rupert, the billionaire owner of Cartier, worth $\$ 7.3$ billion mentioned that he was terrified of robots replacing workers and the poor rising to bring down the rich. Is there increasingly an aesthetic of fear embedded in the aesthetic of luxury - the luxury doomsday and apocalypse bunkers seem to be another hot real estate, have you been thinking about these as well?

AS: I don't see those actual bunkers too differently from these 'bunkers in the sky'. There is a sense of control in both architectures; either you are hidden from below, or from above. But you are never with the rest of society. 


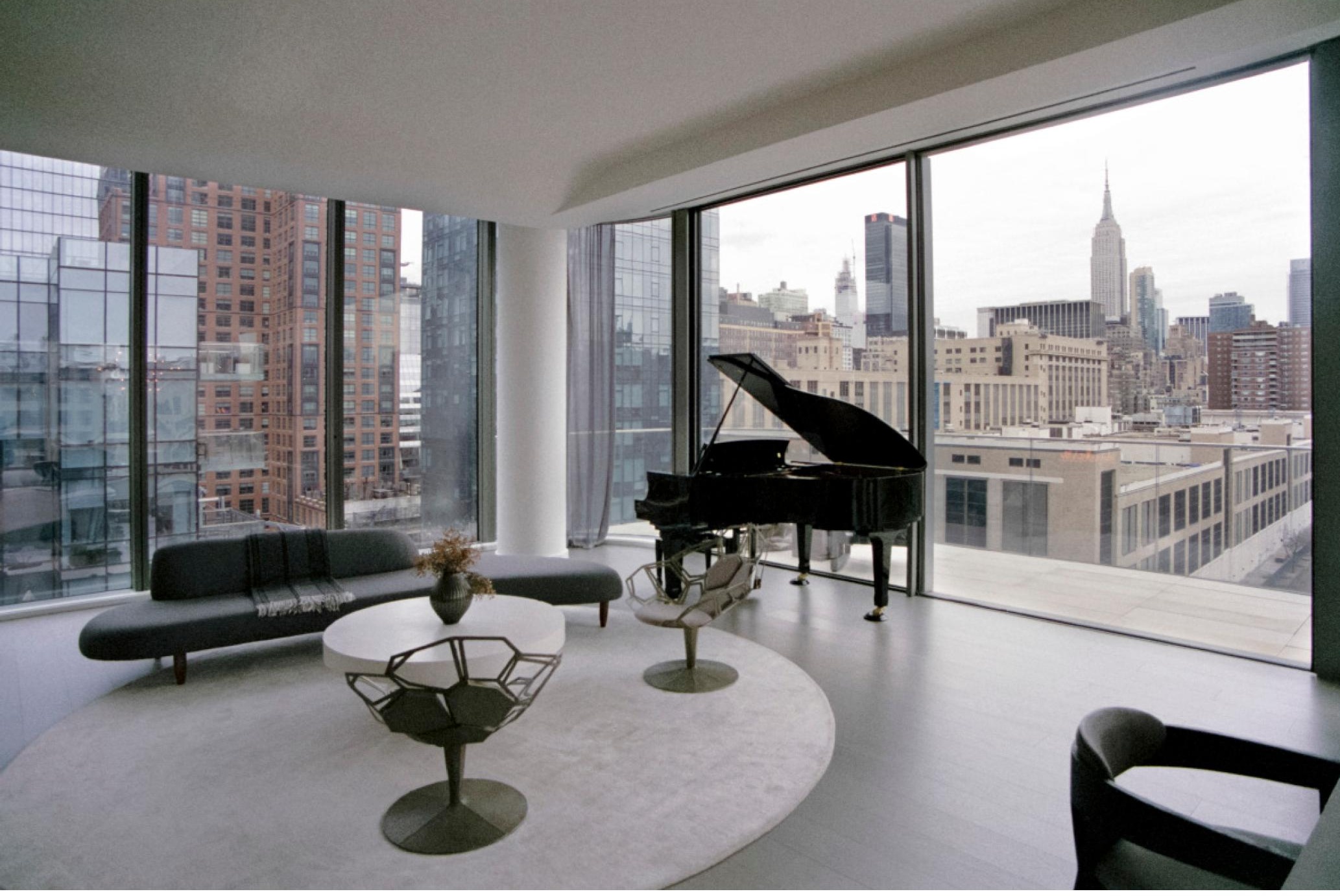

Northern and eastern views from the staged living room of the largest penthouse at Zaha Hadid's 520 West 28th Street. Photo: Andi Schmied. Courtesy of the artist.

AS: What I know is that on average an ultra-high-net-worth individual owns 5 of these properties globally, so they do not live in at least 4 of them. One of the regulations that may be changed, is that if you do not live in the property, you do not pay a certain tax. This is why they don't even bother to rent these places, because that would make them liable for more taxes. The whole thing is about evading. There was one building from the early 2000s that publicised itself in advertising by stating outright that they do not care where your money comes from; owners in that building ended up in prison when beneficial ownership was revealed - at the beginning they were even advertising this secrecy.

TØK: The art market is as efficient at hiding and moving illicit wealth as the luxury real estate market. What functions does art serve in these buildings, and what is the role of artists and star architects?

AS: This has to do with the cultural capital of what is surrounding this ultra-luxury. Be it Zaha Hadid or Frank Gehry, their names are adding a lot to the value of the building. It adds to your value as well, in addition to storing your money. There were some buildings where the architecture was conservative, they look almost like clean old buildings, while others are ultra-contemporary. It is important for the ultra-wealthy to show their taste and 


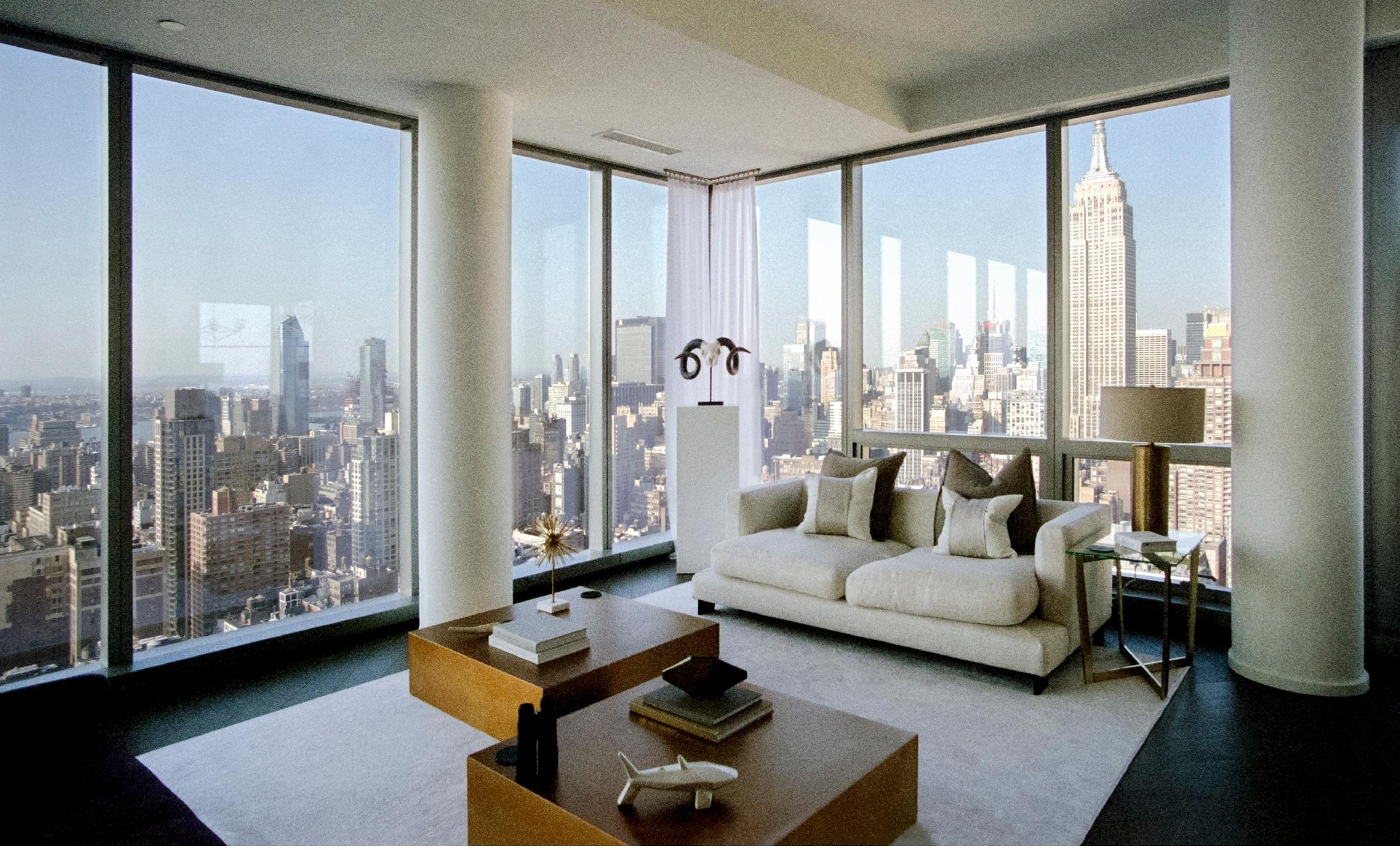

Northern view of the Empire State Building and western view of the Hudson River from one of the upper floor staged living rooms at Cetra Ruddy's One Madison. Photo: Andi Schmied. Courtesy of the artist.

where they belong in this scheme. In a few of these buildings they have sculptures and art pieces in the entrance, like 56 Leonard is 'laying on top of' an Anish Kapoor sculpture. It shows that you have good taste, it is a value. Especially so, when people from the street start to take selfies in this huge, mirrored surface, and hashtag your building. In some places they even told me that 'it is like living in a museum'.

TØK: It seems, however, like staging capital for an invisible Other, by an absent owner. For whom is the illusion staged?

AS: Even though now you should know beneficial ownership, they still keep everything secretive. The agents would say they cannot say who the neighbours are, but they would assure me they were high-level people, often some diplomats, give me some nationality proportions, usually $80 \%$ Americans.

TØK: You also mentioned in the book that many of the owners are the real estate agents themselves?

AS: That is so very often. Someone who rises in the profession, has those skills of selling, a very small range of people, probably not more than 2-300 people in this segment. If you sell one of these apartments, you get around 1-2 million dollars, so after 


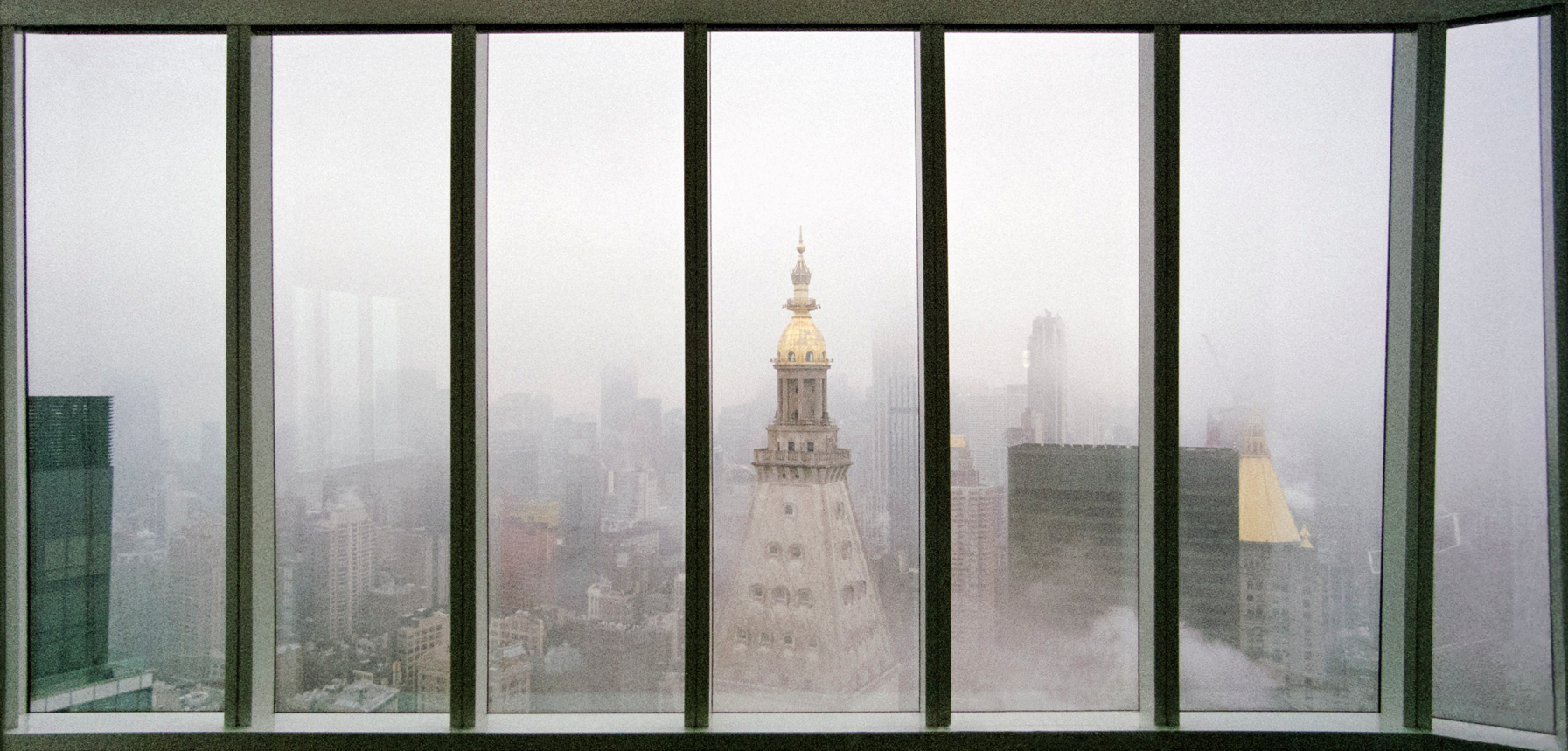

Clouded northern view of the Met Life Tower from one of the upper floor living rooms at Kohn Pedersen Fox Associates' Madison Square Park Tower.

Photo: Andi Schmied. Courtesy of the artist.

could ever imagine or dream of and they always list the architects, designers, psychologists of space, all collaborating to get you the best you can get from life. They buy even respected architectural critics and big names to back the projects, even those who are known to be critical. For example, in the brochure of 53 West 53, the tower above MoMA, Paul Goldberger wrote a text praising the building. They also try to sell the handcraftedness and uniqueness. If you would not see the images but just read the text, you would think that you are in a cottage in a village or something. 'It was made by artisans, in small workshop', and then they throw around names of locations, like Siberian marble, no longer Italian. It was just to make it sound like something else. This name dropping is huge, even marble from the same place as David statue came from, would be highlighted.

TØK: It is just a transfer of imaginary value, a sort of sympathetic magic, overlaid by power over labour power?

AS: Yes, so many people worked for you. There are even these images of dirty hands, working on something, in these brochures.

TØK: Do you see any overlaps between the architecture and aesthetics of affluence and the type of global governance endorsed by the ultra-rich? 

Jin City), utopian architectures (Noguchi Town), or spaces of privilege (Private Views). Schmied graduated from the Bartlett School of Architecture in London and her work, among other places, has been shown in London (Daniel Blau Gallery, Schwartz Gallery, The White Building), Southampton (John Hansard Gallery), Sapporo (Salon Cojica, HUG Gallery), Beijing (Design Week), Rotterdam (International Architecture Biennale), Budapest (Trafó, Trapéz, OFF Biennale, Kunsthalle). She has been artist-in-resident at SAIR, Sapporo (Japan), Triangle Arts, New York (U.S.), DordtYart, Dordrecht (Netherlands), Meetfactory, Prague (Czech Republic), Outpost, Norwich (UK), and MuseumQartier, Vienna (Austria).

Tereza Østbø Kuldova is a Research Professor at the Work Research Institute, Oslo Metropolitan University. She is a social anthropologist and the author of How Outlaws Win Friends and Influence People (Palgrave, 2019), Luxury Indian Fashion: A Social Critique (Bloomsbury, 2016), co-editor of Crime, Harm and Consumerism (Routledge, 2020), Outlaw Motorcycle Clubs and Street Gangs (Palgrave, 2018), Urban Utopias: Excess and Expulsion in Neoliberal South Asia (Palgrave, 2017), in addition to numerous articles. She is currently working on algorithmic governance, surveillance, corruption and crime, and artificial intelligence in policing and the welfare state. She is the founder and editor-in-chief of the Journal of Extreme Anthropology and of the Algorithmic Governance Research Network.

\section{Funding}

Tereza Østbø Kuldova would like to acknowledge the support of the The Research Council of Norway in producing this work, under project no. 313004 - Luxury, Corruption and Global Ethics: Towards a Critical Cultural Theory of the Moral Economy of Fraud (LUXCORE). 